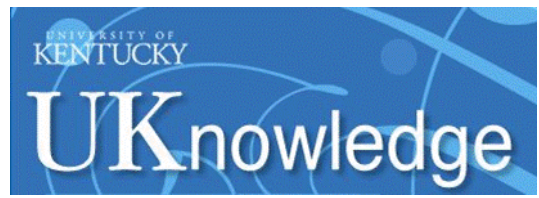

University of Kentucky

UKnowledge

\title{
$5-2012$
}

\section{The Letter of Richard Wyche: An Interrogation Narrative}

Christopher G. Bradley

University of Kentucky, cgbradley@uky.edu

Follow this and additional works at: https://uknowledge.uky.edu/law_facpub

Part of the Legal History Commons, and the Religion Law Commons

Right click to open a feedback form in a new tab to let us know how this document benefits you.

\section{Repository Citation}

Bradley, Christopher G., "The Letter of Richard Wyche: An Interrogation Narrative" (2012). Law Faculty Scholarly Articles. 573.

https://uknowledge.uky.edu/law_facpub/573

This Article is brought to you for free and open access by the Law Faculty Publications at UKnowledge. It has been accepted for inclusion in Law Faculty Scholarly Articles by an authorized administrator of UKnowledge. For more information, please contact UKnowledge@lsv.uky.edu. 


\section{The Letter of Richard Wyche: An Interrogation Narrative}

Digital Object Identifier (DOI)

10.1632/pmla.2012.127.3.626

\section{Notes/Citation Information}

Christopher G. Bradley, The Letter of Richard Wyche: An Interrogation Narrative, 127 PMLA 626 (2012). 


\section{The Letter of \\ Richard Wyche: An Interrogation Narrative}

RICHARD WYCHE

TRANSLATED AND WITH

AN INTRODUCTION BY

CHRISTOPHER G. BRADLEY
CHRISTOPHER G. BRADLEY holds a bachelor's degree in classics from Princeton University, a doctorate in medieval English literature from the University of Oxford (Balliol College), and a law degree from New York University. At the time of submission of this piece, he was lecturer and research fellow at the University of Texas, Austin. This is one of a series of pieces he is writing on medieval law and how we study it. Comments are very welcome at cgbradley@gmail.com.

626

\section{Introduction}

\section{THE DISSIDENT PRIEST RICHARD WYCHE, JUDGED A RECALCITRANT}

\section{HERETIC BY THE CHURCH AND CONDEMNED TO DIE AT THE HANDS OF}

the state, was burned at the stake in London in 1440. Almost four decades earlier, he had been interrogated by ecclesiastical officials in Durham. A record of his ordeal survives, extraordinarily, in the autobiographical narrative translated below.

In this personal account of an inquisitorial interrogation, Wyche transforms his trauma into a sensitive and dramatic memoir. The author's anguished, reflective work takes the form of an extended letter. Nine swiftly narrated confrontations stretch from December of 1402 through spring of 1403. Interspersed are three encounters in Wyche's cell and a scene of prayer and reflection. The letter closes with intimate comments, blessings, and requests. Along the way, Wyche draws on forms ranging from biblical and early Christian martyr narratives to Augustinian autobiography. His writing is laced, at times overwhelmed, by biblical and patristic quotation and allusion.

Few who experienced interrogations before the modern era leave us their stories, and still fewer are as successful as Wyche at combining public drama with novelistic inwardness, or layered artifice with personal urgency. Wyche's Letter is a subversive and transnational work, produced under threat of death and preserved in a foreign land and in translation only; the effort taken to snuff The Letter out, and to save it, lends weight to this engrossing narrative and heightens its appeal. Still, the author refuses to serve as a stereotyped heretic or fit his story into a generalized master narrative. Instead, humanizing details and complicated emotions animate an extended consideration of the limits of institutional demands on individual conscience. Wyche's Letter offers an ambiguous, dramatic meditation on the boundaries of faith, truth, and compromise in the political, spiritual, and social spheres.

\section{Context}

Wyche followed the Wycliffite heresy, which English authorities aggressively suppressed from the 1380s onward.' Sparked by the brilliant Oxford

[ (C) 2012 BY THE MODERN LANGUAgE ASSOCIATION OF AMERICA ] 
philosopher-theologian John Wyclif, this protoProtestant movement called into question key claims of the central medieval social and cultural institution, the church. Wycliffites preached their beliefs publicly and produced-among other contraband texts-a strictly outlawed yet hugely popular translation of the Bible. Though consciously radical, Wycliffites believed they represented the views or inclinations of most average people, particularly of the "gentleman" classes. Wyche is true to form, then, when he addresses onlookers for support, when he too quickly trusts a deceitful knight, and when he argues points learned from a lawyer.

Wycliffites grounded their dissent in the charge that church doctrines did not faithfully reflect scriptural text; theirs was a sola scriptura, avant la lettre. Most controversial was the doctrine of transubstantiation, which defines the extent to which priestly consecration makes Christ present in the eucharistic bread and wine (the host). Late medieval orthodoxy taught that the accidents (physical properties) of bread and wine remained after consecration, but the subject (substance) was completely transformed: no "material bread" (a phrase used in The Letter) remained. Wycliffites doubted this difficult doctrine (Penn). Beyond their disagreement on the meaning of the central element of the central church ceremony lay other disagreements in which Wycliffites denigrated the church's authority-challenging the nature of Christ's "presence" throughout the institutional church. Wycliffites challenged orthodoxy on the sacrament of confession by emphasizing its spiritual, inward dimension, denying any special role for church officials or for quasi-legal penitential procedures. Wycliffites sharply criticized the mendicant orders of friars and thought priestly celibacy unnecessary and apt to promote hypocrisy (though actual sexual abstinence was to be admired). Wycliffite roving priests resisted licensing requirements for preaching outside their appointed jurisdictions. Finally, oaths were problematic because Jesus enjoined the disciples to avoid swearing and say simply yes or no, because oaths were connected to the ecclesiastical authority structures that administered and demanded them, and be- cause oaths sworn on aught but God smacked of idolatry. The Letter touches on each of these controversies, but it avoids lengthy debate on them.

Nor does The Letter require much by way of legal context. The narrative jumps immediately into action, and what Wyche was accused of-corrupting the beliefs of Northumbrians-emerges only gradually and incidentally. Some procedural looseness is not surprising. Unused to prosecuting heresy and lacking institutions dedicated to such prosecution, English ecclesiastics of necessity adapted new procedures within the framework of canon law (Forrest). The process is inquisitorial, a judge-run investigation that blurs the line between what we would call a trial and an interrogation. I favor the term interrogation because it captures the exploratory, ad hoc nature of this proceeding for readers most familiar with adversarial, common law trials. For instance, before a verdict is pronounced, Wyche is twice denounced as excommunicate, but such preliminary denunciations functioned primarily as tools for extracting repentant submission. Even the "verdict" is not final: Wyche eventually signed a recantation, and he occupied several priestly offices after this interrogation. His ultimate punishment followed much later, when he was shown to have stubbornly relapsed into heresy.

Wyche's interrogation culminates in a controversy over an oath, where theological and legal conflicts dovetail. The oath leads to his condemnation but enables Wyche to reverse the charges on his adversaries. Theirs is the bad oath-theirs the untrue faith, in terms of both doctrinal and personal untrustworthiness. Yet even here the narrative avoids triumphalism, taking a self-doubting, almost paranoiac turn to inwardness. Wyche remains destabilized by the unreliability of anyone and anything outside the spiritual assurances flickering deep within.

Readers require no further background to find The Letter a fascinating document. It layers dramatic, ambiguous confrontations over intimate revelations and evokes many biblical and literary parallels without being easily characterized. It stands as a sharp trial drama; a record of struggle over conscientious ideals; a sensitive contribution 
to the literature of confessional autobiography; and a personal memoir of political and religious persecution, challenging widely promulgated official accounts.

\section{Manuscript and Translation}

The survival of The Letter is a story unto itself. We find it in a single manuscript, in Prague and in Latin-probably neither the place nor the language of its composition. But Prague is where Jan Hus's heresy, deeply influenced by Wycliffism, emerged. Hus's followers sheltered Wycliffites and cherished their texts. Thus, while the journey of The Letter remains mysterious, the fact that Hussites and Wycliffites were both heretics of the book may help explain it. Appropriately, Wyche's concluding requests are for forbidden books, described in detail, to be exchanged by subterfuge. His Letter likely survived through similar covert mechanisms, smuggled out of England and incorporated into an anthology of proscribed texts.

Many troubled spots remain in the text, likely deriving from the pressured original writing environment, a hasty translation process, or later recopying; other obscurities or ambiguities emerge from Wyche's richly allusive and textured narrative approach. Wyche often repeats words, shifting their meanings between spiritual and mundane (e.g., "purgation," in the epilogue) and intertwining the practical, pastoral, and personal.

The Letter likely influenced a slightly later, better-known English text, The Testimony of William Thorpe, which better fulfills modern preconceptions of how an impassioned and combative heretic "speaks truth to power." 2 The Testimony may be intended to correct The Letter's inadequacies in the task of rallying the troops. Together The Letter and The Testimony provide the only extant accounts of medieval English interrogations from the perspective of accused heretics.

I have divided The Letter into scenes, following breaks in the ordeal. I supply titles, bracketed, drawn from Wyche's indications of time. I have smoothed periphrastic Latin, modernized punctuation and capitalization, and altered some biblical quotations to make them recognizable. Conjectured readings of corrupt passages are surrounded by daggers $(\dagger \ldots \dagger)$, and omissions of such passages are marked by double daggers $(\dagger \dagger)$. My translation errs toward sense over literalness and is intended as a reasonable and coherent narrative interpretation, not a definitive rendering; for further work, scholars should consult the Latin (Matthew; Gesta), which can support different readings.

\section{NOTES}

Grateful acknowledgments are due to David Armstrong, Anne Hudson, and Fiona Somerset, as well as Holly Crocker, Noah Feldman, Chad Flanders, William Forbath, Steven Justice, Robert Kaster, Ernest Kaulbach, Jonathan P. Lamb, John Logan, Katherine Lu, Elizabeth Scala, Paul Strohm, Marjorie Curry Woods, and the University of Texas, Austin (Department of English and School of Law).

1. For Wyche and his milieu, see n2; Hudson, "Which Wyche?”; Rex; von Nolcken. On Wycliffism generally, see Hudson, Premature Reformation.

2. Hudson, Testimony, and Jurkowski present history and background. Readings can be found in Kelly; Somerset 179-215; Aers 83-98; Kendall 58-67; Steiner, "Inventing" and Documentary Culture 229-39; Hudson, "William Thorpe." On Thorpe alongside Wyche, see Bradley; Copeland 151-219; Schirmer; Summers 108-41.

\section{Works Cited}

Aers, David. Sanctifying Signs: Making Christian Tradition in Late Medieval England. Notre Dame: $\mathrm{U}$ of Notre Dame P, 2004. Print.

Bradley, Christopher G. "Trials of Conscience and the Story of Conscience." Exemplaria: A Journal of Theory in Medieval and Renaissance Studies 24.1-2 (2012): 28-45. Print.

Copeland, Rita. Pedagogy, Intellectuals, and Dissent in the Later Middle Ages: Lollardy and Ideas of Learning. Cambridge: Cambridge UP, 2001. Print.

Forrest, Ian. The Detection of Heresy in Late Medieval England. Oxford: Oxford UP, 2005. Print.

Gesta cum Richardo Wycz. 15th cent. MS III.G.11, folios 89v-99v. Natl. Lib., Prague.

Hudson, Anne. The Premature Reformation: Wycliffite Texts and Lollard History. Oxford: Oxford UP, 1988. Print.

- ed. The Testimony of William Thorpe. Introd. Hudson. Two Wycliffite Texts: The Sermon of William 
Taylor 1406, The Testimony of William Thorpe 1407. Oxford: Oxford UP, 1993. 24-93. Print. Early English Text Soc. os 301.

—_ "Which Wyche? The Framing of the Lollard Heretic and/or Saint." Texts and the Repression of Medieval Heresy. Ed. Caterina Bruschi and Peter Biller. York: York Medieval, 2003. 221-37. Print.

- "William Thorpe and the Question of Authority." Christian Authority: Essays in Honor of Henry Chadwick. Ed. G. R. Evans. Oxford: Clarendon, 1988. 127-37. Print.

Jurkowski, Maureen. "The Arrest of William Thorpe in Shrewsbury and the Anti-Lollard Statute of 1406." Historical Research 117 (2002): 273-95. Print.

Kelly, Henry Ansgar. "Inquisition, Public Fame, and Confession: General Rules and English Practice.” The Culture of Inquisition in Medieval England. Ed. Mary Flannery and Katie Walter. Woodbridge: Boydell, forthcoming.

Kendall, Ritchie D. The Drama of Dissent: The Radical Poetics of Nonconformity, 1380-1590. Chapel Hill: U of North Carolina P, 1986. Print.

Matthew, F. D., ed. “The Trial of Richard Wyche.” English Historical Review 5.19 (1890): 530-44. Print.

Penn, Stephen. "Wyclif and the Sacraments." A Companion to John Wyclif: Late Medieval Theologian. Ed. Ian Levy. Leiden: Brill, 2006. 241-92. Print.
Rex, Richard. "'Which Is Wyche?': Lollardy and Sanctity in Lancastrian London." Martyrs and Martyrdom in England, c. 1400-1700. Ed. Thomas Freeman and Thomas Maye. Woodbridge: Boydell, 2007. 88-106. Print.

Schirmer, Elizabeth. "William Thorpe's Narrative Theology." Studies in the Age of Chaucer 31 (2009): 267-99. Print.

Somerset, Fiona. Clerical Discourse and Lay Audience in Late Medieval England. Cambridge: Cambridge UP, 1998. Print.

Steiner, Emily. Documentary Culture and the Making of Medieval English Literature. Cambridge: Cambridge UP, 2003. Print.

. "Inventing Legality: Documentary Culture and Lollard Preaching." The Letter of the Law: Legal Practice and Literary Production in Medieval England. Ed. Steiner and Candace Barrington. Ithaca: Cornell UP, 2002. 185-201. Print.

Summers, Joanna. Late-Medieval Prison Writing and the Politics of Autobiography. Oxford: Clarendon, 2004. Print.

von Nolcken, Christina. "Richard Wyche, a Certain Knight, and the Beginning of the End." Lollardy and the Gentry in the Later Middle Ages. Ed. Margaret Aston and Colin Richmond. New York: St. Martin's, 1997. 127-53. Print.

\section{The Letter of Richard Wyche}

\section{[1. The Day After I Left You]}

Reverend lord and brother,

May the grace and peace of the brotherhood of Christ be with you, from God our Father and the Lord Jesus Christ.

To show me the path I was to take, God inflicted me with a prosecution the day after I left you, putting me under threat of punishment so that in my soul I would remember the immeasurable punishments that for our sins the Son of God endured in his flesh. To that King of Ages-immortal, invisible, the only God-be honor and glory, forever and ever. Amen.

I accepted this path, and I arrived at the town Chester le Street. I left my saddle and breviary in a lodging near the middle of town, but at Lent I was told that the good master Dees Oknolle had taken them in. May the Father of Jesus give him the sweetness of heavenly life and the purity and blessing of the fullness of grace.

I could not get around well owing to pain from a fall, so I had hired a horse to get there.

\section{[2. 7 December]}

On 7 December I appeared before the bishop. In his presence I denied the alleged doctrines and also denied that I had preached them.

We discussed the mendicancy of the friars. They wished me to publicly approve the 
friars' voluntary mendicancy as an aspect of religious perfection. But I said it was not, because it was contrary to God's law.

They said, "But the catholic church has approved it without qualification. Friars are permitted to beg."

"Paul says, 'All things are permissible for me, but not all are beneficial."

Then they set before me an oath requiring me to swear that I would "obey, firmly and precisely, the laws and regulations to which a catholic person is bound-those contained in the Decretum, Decretals, Sext, and Clementines."

I requested counsel and a hearing date.

They said, "No. But you may have time until after our meal. You will figure it out-if you want to."

So, after the ninth hour [3:00 p.m.], I appeared before the bishop. He admonished me once, twice, and a third time to swear the oath, then and there. I gave no word in reply. He denounced me as an excommunicate and sent me to a cell. Thus they persecuted one whom the Father, in his grace, was striking along the way. They heaped more onto the pain of my wounds.

I asked the bishop to have my horse taken to his stable, and I gave what I had in my purse to the man leading it there.

\section{[3. The Following Saturday]}

I was led before the bishop again the following Saturday. He asked, "Who licensed you to preach in my diocese?"

"Wherever I preached, I had license from the rector of the church," I replied.

"Rectors do not have the power to license anyone."

"Our law gives a rector the license to choose any fitting priest to help him in his ministry."

"That is not so."

We exchanged many other words about this issue, because I said that every priest is bound by the law of God and by canon law to preach the gospel of Christ and to study the law of God. I cited the gospels, Gregory, and other teachers in support of my view-after all, they said we should perform wonders as they did.

The bishop said, "We suspect you are one of the sect of the lollards, who do not believe the truth of the Eucharist. Therefore, let us hear what you believe about this article of faith."

"I will gladly confess my faith to you. I believe that the Lord Jesus took bread on the night he was betrayed. He gave thanks, blessed it, broke it, and gave it to his disciples, saying, 'Take and eat of this, all of you. This is my body.' Likewise, I believe that after the consecration, the consecrated host is the true body of Christ, and the same host, divided into three or however many parts, is the true body of Christ in the form of bread."

"Do you believe that after the consecration of the host, the true flesh and true blood of Christ are there?"

"I do believe," I replied, "that the host is the true flesh and true blood of Christ."

"But is there still bread there after the consecration?"

At this I was somewhat troubled, not having the Spirit of great counsel that should speak through me.

The archdeacon of Durham said, "See how he wavers in the faith!"

"Not so. I believe that the host is the true body of the Lord, in the form of bread."

The chancellor said, "That is false. It is not the body of the Lord in the form of bread."

The archdeacon added, "It is the body of Christ in the appearance of bread, not in the form of bread."

"Then all the people are outside the faith," I replied.

I looked to the people there and asked, "You believe that the Eucharist is the body of Christ in the form of bread, don't you?"

"No," they answered. But I believe yes. 
The chancellor then said, "Is the material bread still there or not?"

I said, "The holy scripture does not call the host 'material bread.' Thus, I do not wish to believe anything about that as an article of faith."

Many similar discussions followed, but this was the way that day went.

\section{[4. After Christmas]}

I was sent to my cell until after Christmas, when I was led before the bishop's council and an Augustinian master [of theology] from Newcastle. The archdeacon told me to explain my belief about the Eucharist, and I did, just as written above. Two knights, seated to the side, commented, "It seems to us that he believes rightly."

But the master asked, "Are accidents separated in the host?"2

"They are separated."

The archdeacon asked, "But is the host still material bread or not?"

"I am not bound to believe anything other than what the holy scripture speaks. I believe that Christ took the bread in his hands and said, 'This is my body.' That is sufficient faith for any Christian. I do not want to mix myself up with 'material bread.' For a Christian it is enough to say just what the holy scripture says."

Then the archdeacon asked whether I would swear the oath.

"No."

"Why not?"

"Because it follows from the oath that every priest in mortal sin has no power to consecrate the sacrament of the altar or to 'bind or loose."”

"How is that?"3

"If anyone transgressing the law of the Lord sins mortally, and such a person does not have that power, then such a conclusion logically follows."

"How does the minor premise run?"
"Thus: anyone transgressing the teaching of the apostolic see has no power to consecrate. Therefore, a fortiori, someone transgressing the teaching of God has no such power. The major premise is this: anyone transgressing the precept of the apostolic see is a heretic. Since a heretic has no power to consecrate, my conclusion follows."

"You must prove the minor premise," they said.

"That is a text in your law," I said.

"It is not," the chancellor replied.

"It certainly is," I said.

The master glossed the text otherwise. But by virtue of the oath, the text bound the affiant to the law, not to the gloss. And that is how it seems to me the argument is proved.

They asked my view about whether oral confession was necessary for salvation.

"It is necessary," I said.

The chancellor replied, "God knows you will tell us when and to whom it must be done before you leave."

"As God wishes, let it be done, as far as I am concerned."

They scorned me. Among a number of other words, I added, $\uparrow$ "For all their confessions, they do not cease their sins." $\dagger$ This was how that day went.

\section{[5. The Next Day]}

The next day the Augustinian master came to me in my cell and offered me tempting advice. He promised that his lord the chancellor $\dagger$ or the bishop would advocate for me if I would reach an agreement with them. Even if the things I said were true, he said, nevertheless I should yield to them because everyone was unanimously against me. $\mathrm{He}$ said that he himself would heartily advocate for me and pray for me in particular during mass for a year.

"You should make sure," I said, "that you will find your actions sufficient for yourself on the day of judgment." 
He said, "Unless you follow their instruction, you are looking to be burned."

"As God wishes, let it be done."

He left.

\section{[6. About Three Weeks Later]}

About three weeks later, I was brought before the bishop, and he asked why I refused to swear the oath before him. He said, "We love our souls just as much as you do yours."

"It is certain that I am not bound to obey anyone's law or commandment except insofar as it is consistent with God's laws-and to that extent I will gladly obey."

"Who will sit as judge to determine what is 'consistent with God's laws'?"

"Is it not God's law itself which will judge us in the last day-as Christ himself taught?"

A Franciscan friar, a master of theology, was there. The bishop praised him and asked him to say how long he had been a master. For forty years, he said. The master extensively praised the papal laws. Then the bishop asked again why I would not swear the oath.

I said that it was because there was a law saying that a man who had been joined to his mother in matrimony could not be released from her-according to the laws, he had to treat her as his wife. A Christian could not be bound to this law, and there are many divorce cases in which a catholic cannot be bound to obey the law. I posed to them the case of a son married to his mother.

They replied that there was no such law on the books, but I insisted that the law on the books was that they could not be divorced in such a case. Again they scorned me.

Then the chancellor read out a law forbidding priests to be married. They asked me whether I approved of that law.

"Would that priests would strive to keep that law!"

"But that law is contrary to one of Paul's writings," he said.

"How so?"
"Paul said that each should take a wife."

"He did," I said, "but he added 'on account of fornication."”

"Well, then," the bishop insisted, "'on account of fornication' each should take a wife."

"Yes, I understand that to mean that a priest should take a wife rather than commit fornication."

Thus they tried to demonstrate, as the chancellor asserted, that papal law held greater authority than Paul's preaching.

Then the master said, "You should obey your superior, for Paul teaches, 'Obey your superiors."”

"I want to behave just as he commands, because he said, 'Obey your superiors as you would God.' Since God must not command anyone except to fulfill his own commandments, you can order me to follow God's will. I will fulfill that, if God wills. You are his ministers, and you cannot teach anything except what Christ teaches in you. For Peter says, 'If anyone speaks, let him speak as if speaking the speech of God."

Then the master said, "Oh, when have you heard Christ speaking in you?"

"Whenever I hear his words spoken by anyone."

Much more was said, but this was the gist. Afterward I was sent back to my cell for ten days.

\section{[7. Later]}

Later a knight was sent by the bishop to discuss the oath. He seemed a reliable man. The chancellor and a notary priest came with him, and they remained standing while he sat down.

The knight said, "Richard, I fervently desire a good agreement-work fervently for one! I implore you, tell me why you do not want to swear the oath."

I gave him three reasons. One was what I had told the bishop about a son espoused to his mother. The chancellor said this case was not anywhere in the entire law. 
I said, "Nevertheless, the case could happen. In many divorce cases occurring all the time, the faithful are not bound to follow the law, because if they do they will infringe the command of God."

"How do you propose to judge in such cases?"

"God knows."

The knight said, "This issue is not relevant to your oath."

"Very well. Another reason is that in a case where someone is unjustly accused and the judge knows it-even if the accuser brings false witnesses against the innocent defendant-the judge is obliged by law to convict the innocent, which a Christian judge should not do."

"That issue is not relevant to your oath either."

"Very well. Another issue is that whatever other laws or regulations someone is bound to obey, he remains bound to fulfill the laws contained in the four books [of canon law]. $\dagger$ But $\dagger$ you are not bound to obey anyone's law or precept except insofar as it is consonant with the will of God. †For example†, a layman is not bound to obey the laws pertaining to the office of the pope, bishops, or priestshe is not bound to fulfill those laws."

"Well said," he answered. "I am not obliged to sit and hear confessions."

Then he said, "Richard, can you find it in your conscience to obey the law of the catholic church insofar as it pertains to you?"

"Certainly, because I know that the law of God is the law of the catholic church. Far be it that I should not obey the law of our God insofar as it pertains to me."

"Well said. Keep that in your heart, and let it be your oath. You will swear it as you have limited it in your heart."

"Very well, my lord. Except that, as you know, if I take an oath from a judge, I have to receive it according to the intention of the judge, not my own intention."

"You may be certain my lord will accept this oath from you, because my lord sent me to negotiate it with you. If you are willing to do this, my lord will absolve you from other oaths, and you will have a good outcome. This is better for you than to remain imprisoned."

"I would gladly be set free-if God wills it."

"But beware of one thing: whatever oath he shows to you, do not press questions about it, because a subject should not press questions on his superior. A pot does not ask the potter, 'Why did you form me for this purpose or that?' My lord is somewhat obstinate. If you agree to this resolution, I will, if you wish, go to my lord and arrange it."

"I agree, gladly, if my lord will do as you say and receive this oath from me limited in my heart: that is, that I am bound to obey the law of God insofar as it pertains to me."

"Do not doubt it."

The chancellor added, "By God, you will swear just as we want you to, before you leave here!"

I did not reply.

The knight got up, and, standing in the doorway, asked, "Richard, in faith, will you keep your promise as you have said?"

"Certainly-if my lord keeps to the agreement as you have said."

"Certainly. You may be sure of it."

He left. This happened on Saturday after the ninth hour.

\section{[8. The Following Day]}

The following day I was led before the bishop, at about the first hour [6:00 a.m.]. They gave me the text of the iniquitous oath. I read it through three times, and this was its sense:

I, Richard Wyche, of the Worcester diocese, swear that each catholic is bound firmly and precisely to the laws and regulations contained in the Decretum, Decretals, Sext, and Clementines, and insofar as they apply to me I will obey them.

If it happens that I later preach something contrary to them, I admit that I will have fallen into heresy. 
If I have any books contrary to them, I will send them to the bishop around Easter.

When I had read that oath, I thought about the agreement that I had undertaken not to press questions about the oath they gave me. I went to the knight, who was standing by the fire in front of the bench, and said to him, "This is not the oath that was agreed on. I will never swear this oath."

"Will you not swear it with the limitation in your heart?"

"Very well. I will."

The bishop was sitting on the bench, and I knelt before him. I said to the bishop, "My lord, if you wish, I am willing to swear the oath I agreed to swear, as limited in my heart by my lord this knight."

"Then swear. Place your hand on the book."

I put my hand on the book. They read the oath, and when they finished, I kissed the book, hoping that the bishop would not try to extract anything from me beyond the agreedon oath-if he even wanted the agreement, and if truth was to be maintained.

But they gave me another oath to read and to swear, concerning the doctrine of the Eucharist, and yet another, on confession. The oath about the Eucharist began thus: "It is catholic to hold what is written below...." (After they saw I would not swear it, they sent it to me in my cell for me to write out.)

I told them I would not swear the oath about the Eucharist, and the old master, the friar, said, "You are bound to swear this oath by virtue of your other oath. I feared there was deceit in that oath."

"I am not bound to swear it, and I will not swear it."

Then the bishop cited Berengarius to me and ordered them to read me his recantation. They read me that "that which everyone was bound to believe could not be against the gospel."

"As Christ spoke, so I believe," I replied.
"What do you believe about the first item?"

I answered the same as above. I asked the bishop to point out to me in the law of God anything he wanted me to believe as an article of faith.

The master said, "You do not want to believe anything unless we point it out to you in the law of God?"

"I do not care who points it out to me. I will believe it, whether I hear it from Christ or from man, because it is altogether right for me to. For faith comes from that which is heard, and hearing comes through the word of Christ. †And a bishop should come to his faith the same way. $\dagger$ "

But he replied, "Augustine said, 'How shall I believe that a doctrine is the law of God save that the church approves it?' It follows that because the church approves this oath, it is right for us to believe it is proper doctrine."

"Certainly, I know the church is founded on a rock-that is, on faith. Not faith on the church. That is what Augustine taught: 'If Augustine says it, do not believe it-but if Christ says it, woe to him who does not believe!"”

The bishop said that James and I were corrupting the people in Northumbria.

The master, the Franciscan, asked from where I derived my belief that the host is the body of the Lord in the form of bread, and he asked whether the "form of bread" is material or not.

"I have never seen this word, 'material,' in holy scripture. But Paul says, 'The bread that we break, is it not the sharing of the body of the Lord?"”

"Look, he speaks heresy," said the friar, "for he says it is bread."

"The words are not mine, they are Saint Paul's. Judge him a heretic, if you wish, because of God's law. No one should add to the law of God or take anything away from it."

"That is not true," they said, "because some sayings have been added to the wordsfor instance, by saying 'For this is my body' when Christ said, 'This is my body.'” 
"That is not an addition but an affirmation."

Much was said along the same lines. They demanded that I swear that oath about confession-which was, in effect, that it is necessary for the salvation of the soul of each person to confess orally. We did not have to disagree about this, because although the good Wyclif denied that doctrine, he denied it using sophistic ways of speech. Thus, I compromised, using scriptural ways of speech: "Every virtue is necessary for the salvation of anyone's soul."

The chancellor said to the bishop, "Lord, ask him when he was last confessed."

So he asked me, "When-and to whom?"

"My lord, I am not bound to praise myself or to condemn myself. But in fact I was confessed about six times, not long ago."

We exchanged many other words, and the bishop told me I could think out my reply about the oath of the Eucharist until the following Sunday. He set my next appearance before him for that Sunday, at the same place and time.

\section{[9. Three Days in the Cell]}

I was sent back to the cell, and for three days I was in great sorrow and affliction of spirit about that poisonous oath-not knowing how I should act if the bishop did not hold true to his agreement about the oath.

God the Father let me go, in a sense, so that he could later bring me back again. The Father of Lies swirled deceptive, rushing temptations around me to lead me astray. In great difficulties, I called to the Father of Lights-he who comforted Daniel and snatched him from the lions' den-to comfort me and release me from my tribulations.

I said, "Lord, this is your case. You know what hangs on this, even though I, for the multitude of my sins, am not worthy of living on your earth. I want to fulfill your will. If I fall short, the reason is either the detestable sins of my youth, or ignorance. Therefore, heed me and the sins of my youth,
Father, and according to your mercy be mindful of me and rescue me from the hand of this unjust sinner working against your law. Protect my soul from intending anything contrary to your will."

The kind Father, seeing my affliction, was mindful of the passage where he says, "He called to me (and so on), and if he shall persevere to the end, I will glorify him." In his grace, he reminded me of the agreement with the knight and the manner of agreement, as written above: how I had never thought, nor had it arisen in my mind, nor had I ever intended to swear their oath, but only the oath limited by the knight.

I rejoiced in the Lord. My heart was opened by the Lord Jesus, who snatched away my soul, unharmed, from this most iniquitous oath-though I fear, sorrowfully, for their souls, which are most basely defiled. For, as the prophet says, "They have hidden their net unto my destruction; they have rebuked my soul for no reason. Let them come upon their net unawares, let their hidden deceit catch them, and let them fall into that trap themselves." But my soul will rejoice in the Lord and delight over his salvation. Therefore, blessed be God, the Father of our Lord Jesus Christ, the Father of Mercies, the God of all consolation, who consoles us in every tribulation, because, "My sons, look at the nations of men, says the wise man, and know that none has hoped in the Lord and been confounded or has remained in his commandments and been abandoned. Now let us sing to the Lord, for, gloriously, he is magnified: he has cast the horse and its rider into the sea. The Lord has become my strength and my glory, in the salvation of the cross."

Then, most beloved, it came about that the day of my summons to appear before the bishop passed, and no one sat in judgment or issued continuance of process. I had heard from lawyers that if anyone who stands under accusation has a hearing scheduled and no one sits in judgment or issues a continuance, 
the accused does not have to appear unless a new process is initiated. Thus, I was glad that the day passed.

\section{[10. The Sunday After]}

The Sunday after the appointed day, I was brought before the bishop by a summons. They read Purvey's abjuration to me, and they wanted me to believe just as he did in his recantation.

"My lord, if you please, either the laws in the south are anomalous, or you have no legal process against me."

"Why so?"

"In the south the accepted law is that if anyone has to appear before a judge, and he appears but finds no one sitting in judgment or issuing a continuance, he cannot be held over without a new initiation of process."

The chancellor said, "My lord knows more about the law than you."

"I know this because those skilled in the law have taught me about it," I said. "I know someone who appeared before judges who gave him a place, day, and time to appear. And since he appeared but found no one sitting in judgment or continuing the process, they did not and could not do anything further to him without initiating a new process. The man himself related this to me-he still lives in the city."

Then the knight with whom I had dealt said, "You are not accused in an adversarial proceeding. Rather, the judge himself accuses you."

"Surely, if a man who is not in custody but is at liberty, who can have counsel if he wishes to defend himself, who has by law a set place and time to appear, and who appears but finds no one sitting in judgment or issuing a continuance-if a man in that situation is no longer bound to appear without new initiation of process, surely it should be all the more so with me, imprisoned without visitor and without counsel. You cannot, without a new process, legally proceed against me further."
Then I continued, to the bishop, "My lord, I have nothing to do with that abjuration. But I am prepared to speak my faith concerning the Eucharist to anyone."

"Speak, then."

I spoke just as before. When I had spoken, I asked the bishop, "Is this not the church's doctrine?"

"Yes," he said.

"What more do you want from me?"

Then the knight spoke up: "You say that Christ said, 'This is my body.' Therefore, it is right to believe that this is only his body, and thus not bread."

"It is sufficient for each faithful person to believe as Christ said, not adding to his words."

Then the bishop said, "Certainly, either he is outside the faith-or we are."

He was right about that.

\section{[11. The Next Day]}

I was returned to my cell, and the next day the bishop sent this note to me there, through the chancellor:

It is catholic to hold and believe that the bread and wine, which are placed on the altar by the consecrating office of the priest after the words of consecration, are transubstantiated into the true body and blood of Christ. After the words of consecration, the bread and wine placed there before do not remain, but the body of Christ is there.

After that argument is read, my lord wishes for R.W. to respond to the conclusion above and to the specific issues raised there-to give a precise exposition of his understanding, how he regards them, in writing. He should write this in his own hand.

I said that I did not know how to "give an exposition" of my position.

He said, "I will leave this note with you until nighttime. Here is paper and ink. Do whatever you please." 
"Certainly, if you were going to treat me lawfully, you would no longer have an ongoing process against me."

"Oh, who has made you a man of law? Are you going to teach us to know as much of the law as you do?"

Thus, since they could not catch me with my speech, they tried with an "exposition." The next day, he came to see whether I had written out my position.

'I am not a writer of 'expositions,' and I do not know how to 'give an exposition' like this," I said. "Nevertheless, if you will provide me with a Bible, I will gladly write down what I believe."

He gave me the scripture and left.

\section{[12. Before Ash Wednesday]}

Afterward, on the Monday or Tuesday before Ash Wednesday, I was led into the presence of a White Canon, with the master friar mentioned before. The master spoke many words, suggesting that because I was not a cleric of approved orthodoxy I should take counsel from clerics who were and accept their teaching.

"Certainly, I am prepared to be taught by anyone-according to the law of God. For, as Augustine says, 'If anything is evil, it will be condemned there; if anything is useful, it will be found there, and more plentifully there than anywhere else."

The canon, who seemed very modest, said, "My lord Richard, as it is written in canon law and ascribed to Solomon, 'My son, do not rely upon your own wisdom,' and again, 'My son, do not be wise in your own eyes."'

"Certainly, I hope that nothing I am saying or have said comes from my own head or my own perception because if I say anything from my own head, then I am acting contrary to Solomon's counsel."

The master said, "The entire church believes that the Eucharist after the consecration is not bread but is the true body of the Lord."
"Point out to me that 'not' in the law of the Lord, and I am ready to believe."

"Oh, here is the bishop's butler-but you will not believe this is the bishop's butler unless you see the butler's keys in his hands."

"You are a master. You should not use the law of God flippantly in support of your arguments. For me to believe you about the bishop's butler is not to believe anything of doctrinal weight."

"Surely," said the master, "this is sound reasoning: the sacrament is the body of the Lord, and therefore it is not bread. There are many good reasons to believe that it is not bread. After all, the Lord, when appearing in the bush to Moses, said to him, 'Throw your rod away from you.' He threw it, and it was turned into a snake. In the same way, the bread is turned into the body of the Lord."

"Neither scripture nor scholars say that the substance of the rod was annihilated or destroyed. Rather, they say that it was turned into a snake."

"Notice," said the master, "how he says the rod was not turned into a snake!"

"I am not saying that."

I addressed the White Canon. "I ask you, sir, to attest to whether I said that."

"You did not say that," he said.

"My lord, I will explain to you my belief about the Eucharist." I explained it, as always, in the same way as before.

"I know," I said, "that all the people believe this. I have believed from my youth that the consecrated host, white and round, is the true body of Christ in the form of bread, and I will believe it to my death, God willing. The great Augustine believed the same way. He says, 'What is seen is bread, but what faith posits for belief is that the bread is the body of Christ."'

The chancellor said, "Do you believe that the host, consecrated in the hands of the priest by church custom, is the true body of Christ?"

"I believe that sacrament is as worthy as the sacrament that Christ held in his hands and gave to his disciples." 
"I ask you, Richard, to agree with the bishop. The day is coming when the bishop will sit in judgment, and he claims to have sufficient legal support to adjudge you a heretic."

"Very well, so be it, in the name of the Lord. God knows that I have asserted nothing beyond the law of God or what can be expressly based on sacred scripture. If he wants to judge me a heretic for that, I will gladly suffer it."

"Let us go," said the master. "He is incorrigible. Why should we stay with him?"

They left for their midday meal-and I left for my cell.

\section{[13. Fifteen Days Later]}

Fifteen days later, without a summons, I was led before the bishop, sitting on his throne near a fire. In front of the fire on a bench sat the knight whom I had dealt with, the archdeacon of Durham, a monk named Rome, and two masters-one a preacher called Paris and the other the Augustinian prior of Newcastle. The members of the bishop's household were behind them, but I was between them and the fire.

The chancellor, standing in front of the bishop, said, "Sir, my lord asks whether you will write down your position and respond to each and every point written here."

I replied to the bishop, "My lord, if you wish to act according to the law, you have no ongoing process against me." I explained the issue to them, as written above. Then they pointed to the evil oath and stated that I was bound to what was written, by virtue of my oath.

"Certainly," I said, "I never intended, nor have I ever thought, to swear that oathrather only the oath agreed on with this reverend knight, the oath that was limited in my heart. The limitation was that I am bound to obey the law of God insofar as it pertains to me. This I am prepared to hold.

"Lastly," I added, "at that very time I told this honorable knight with whom I dealt that
I would never swear the oath. You said to me then, 'Swear the oath limited in your heart,' did you not?"

The knight denied it.

"God knows," I said to him, "that is how it was."

I told the bishop, "My lord, at the same time I told you that the oath I would swear-if you wished me to-was the one limited in my heart by the knight according to the agreement. You said, 'Then swear it,' so I believed you. God knows you will not get anything from me aside from the oath limited in my heart, which was just as the agreement would have it. I said so then, and the knight told me that if I wished to swear that oath limited in my heart, you would relieve me of further oaths provided I did not press any questions. $\dagger \dagger "$

"How does that differ from the oath you swore?"

"In every way. The agreement has not held at all."

I added, "It is a great sin for a man to deal treacherously with his brother."

The knight rose. "Are you saying that I dealt treacherously with you?"

"I am not saying that, because I do not know your heart, nor do I know whether I should say it about you. But I do say generally that it is a great sin for anyone to deal treacherously with his brother."

Then the bishop said, "Richard, you cannot tell us that you have not sworn this oath. There are two notaries and many others here who will swear that without any application of force you willingly swore this oath."

"Certainly," I said, "if they knew the manner of the agreement and if they feared God, they would not testify against me. But I call on God with all his saints to testify for me on the day of judgment that I never thought, nor was it my intention, nor has it ever arisen in me to swear this oath."

Rome said to me, "Richard, for shame, do not be found false. Look, everyone testifies against you." 
I replied to him, "If I say that I swore it, then I would be most false, because God with all his saints knows that I have never thought of doing so." We exchanged many other words, ultimately dealing with the sacrament of the altar, about which I maintained myself continually in the same way as written above.

Then the bishop said to me, "Richard, you are going to be a relapse. Therefore, be careful."

"My lord, you may do with me what you will."

He warned me once, twice, and a third time, ordering me to give written response to his writing. But I did not respond.

He denounced me as an excommunicate and right away gave summons for me to appear at the same time and place the next day.

\section{[14. The Next Day]}

The next day I appeared before him as he sat on his throne and the friar Paris with the archdeacon sat on the bench. The other three stood further back, and the people of the house were behind them. I stood beside the fire. The chancellor stood in front of the bishop. He said, "Richard, my lord requests from you whether you now want to write down your position. If you will do so, my lord will be gracious."

I said to the bishop, "My lord, if you please, lawfully initiate a new process against me."

Paris said, "Richard, I am amazed by your claim that no one may add to the laws of God. For then the entire church errs, because the church adds 'the mystery of the faith' to the words consecrating the blood. Neither Christ nor Paul, who alone taught the words of this sacrament, taught those words."

He read in a Bible from Matthew, Luke, and Mark, along with Paul.

"See, Richard-those words are nowhere to be found."

"Certainly," I responded, "Paul has those words in many places."

"That is not so."
"I know for sure that it is so. Nonetheless, we should understand that the law of God does not exist chiefly in letters, in parchment and ink. If it did, the law of God would be very false, because many Bibles are full of errors. Moreover, then the law of God would come to an end with the end of this world, and that would be against the word of Christ, who says that 'Heaven and earth will pass away, but my words will not pass away.' I know that knowledge about Christ is not increased or decreased by these words, so they are not an addition."

I asked the friar if I could read Paul in the same place a little later, when he explains that the sacrament is bread.

"No," said the bishop, "it would take too long to read from Paul now, since the sacrament is nothing else but the body of the Lord."

"The great Augustine," I replied, "says, 'That which is seen is bread."'

The archdeacon said, "It is spiritual bread."

"How can the sacrament be spiritually anything other than the body of the Lord?"

I took a straw in my hand and added, "Is it possible that Christ could stand here personally and say 'This is my body,' and that I could not believe that this was his body?"

The bishop commented, "He certainly defends his error obstinately." Then he told the chancellor, "Read the verdict. I am giving my voice to you, because I am hindered by this sickness."

The chancellor said, "Richard, you have told me that you did not know how to 'give an exposition' for your response. However, we know what it is, because we have enough of your exposition."

Therefore, he gave a verdict that excommunicated me with the greater excommunication, held me to be a heretic, left me in custody until they could find the time to degrade my priesthood, and ordered confiscation of all of my movable and immovable goods.

In this way, despite my protest, they judged me a heretic-without lawful process, 
it seems to me. Because of that, I did not know what to do next, nor what I had to do. He based his verdict on an oath I never thought to swear. Moreover, it seemed to me that even if I had freely chosen to swear that oath, I was not bound by law to obey it, because at the beginning of the oath was written "I, Richard Wyche, of the Worcester diocese." I am not that person, because I am not of that diocese. Therefore, the oath could not bind me.

Who ever heard of such an astounding judgment!

After the judgment I appealed to the pope, but they said, "You have come too late."

"In the name of the Lord!" I said.

The friar Paris responded, "By God, God has done greater good in judging you a heretic than if he had brought a thousand paupers to a feast."

"For what am I a heretic? I have said nothing beyond the law of our God. Surely, if Christ himself could stand here before you, you would judge him a heretic, just as you have me."

I said to the people there, "I ask you to witness that this is my faith, which I have spoken out in their presence six times: I believe that the venerable sacrament is the true body of Christ and his true blood, in the form of bread."

\section{[15. Epilogue]}

He sent me back to the cell, where I remain-with sufficient food and drink, thanks be to God.

Our good God, by his grace, has visited me with a serious constriction in my bowels, which sometimes has made and still makes voiding my bowels extremely painful. Because of this, I have sometimes gone nine days without one real purgation-I have had hemorrhoids twice, and I am ashamed to speak of how profusely they made me bleed. Nevertheless, it is necessary for me to do it or not to live. My purging is difficult, just as his purging was.
These are my secrets. Therefore, if you please, keep them secret. I do not write much more to you. Send to Whitby that he should secretly meet with my lords of Balknolle and Winkfield, when you see an opportunity. Greet John Maya and his wife for me, with this greeting: that they may pursue quiet and rest in all piety and chastity.

For to greet in that way is good and pleasing in the eyes of our God, who gives grace through his word to become his children to those who heed as very dear children the passage where he says, "If they call the father of the house Beelzebub, how much more will they so call the servants of the house?" And again, "If the world hates you, know that it hated me first before you. If you were of the world, the world would love that which was its own. But because you are not of the world and instead I have chosen you out of the world, therefore the world hates you. Remember therefore my words I have spoken to you: 'The servant is not greater than the master.' If they persecuted me, then they will also persecute you." These words are very true.

Therefore, if they wish to be of the family of God, let them submit themselves, for the sake of God their savior, humbly to suffer the reproaches and detractions and scandals of this kind. Let them focus with the eyes of their minds on Christ, the head of our family, who suffered infinite pains for our sins. And these things will not be harmful but will bring on a joyful mind and the blessing of God, as the Master attests: "Blessed are you when men hate and reproach you and spurn your name as evil on account of the Son of Man. Rejoice and be exceeding glad because great is your reward in heaven."

I ask you to greet their daughter for me and to tell her to maintain her virginity for her spouse, Christ, and not for the world. Because if she glories in her virginity for the sake of worldly praise, she saves it for the world and not for her most fair spouse, Christ. If she glories in her pure virginity to 
be praised by her most fair spouse, Christ, then she is Christ's virgin, saving herself for Christ, her spouse, and not for the world. This is the angelic way, and as the Spouse says, "His angels always see the face of my Father, who is in heaven," because purity of mind, kept from the corruption of the enemy, is an angel through whom a person can see the Father and the Son and the Holy Spirit, one God, living in the soul as a king on his throne.

Therefore, let her pray to God day and night in his infinite providence, if it pleases him, to wed her bodily and provide her with a spouse. For since he is infinite in beauty, who could resist him? She should not choose a spouse for herself, for since he is infinite in wisdom, who could better select a spouse? Since he is of infinite love and by his love always ordains best for his creatures, therefore she may say in her mind, she may clearly say, with the Psalm, "Hope in the Lord, do good, inhabit the earth, and you will live in his riches. Delight in the Lord, and he will give you your heart's desire."

Show your way to the Lord, and hope in him, and he will cause you not to fall into the carnal lusts that war against the soul. For as the angel says, "He has given the devil power over those who enter into marriages so as to exclude God from themselves and their minds and to abandon themselves to their lusts just like a horse or a mule with no understanding." Therefore, let her say, with Sarah, "Lord, you know that I have taken a husband not from lust but only because of the love of posterity, that he may see the sons of his sons in peace over Israel forever and ever. Amen."

Greet for me my brother Robert Earl, who for God's cause, and in a sense for me, has suffered condemnation. For I was told, around Lent, that the bishop's chancellor went to Newcastle to find some lollards and found there some master of the lollards named Robert, who had come to visit and sit with me, to comfort me. I hope that God is preparing better for him. Let him prepare himself to imitate the most sweet life of Jesus Christ. He can say with the apostle, "Thanks be to God that I am what I am and that his grace in me has not been in vain." May he not lose the grace that the heavenly Father has given him in his great love. For since our Father gave his only Son to the greatest pains and reproaches on account of the love he had for him and for us wretches, how can it be that our Father, giving anyone to pains and reproaches of this kind in this most wretched world-in which life, compared with the heavenly life, may be called death rather than life-will not love, from his great treasure trove of love, those who love him.

Heed, therefore, how the earth-born prefer the testimony of the dead, while the heaven-born prefer the testimony of the Lord of Lords. The fount of every treasure is, by his testament, sent not to the disciples who love worldly prosperity and mundane pleasures but rather to those who choose painful afflictions, tortures, rejection by the people, and even a weighty death. Because he himself says in his testament, "They will deliver you to councils," and so on, "with scandals and evil words, and they will bring you to testify before kings and princes on account of me." Elsewhere he says, "They will cast you out of the synagogues with excommunication. The hour approaches when anyone who kills you will think that he is serving God. They will do these things to you because they have not known my Father or me."

So let him say, "How sweet are your sayings to my lips-greater than honey to my mouth, for from these come eternal life." Did not Christ bear witness, saying, "You are those who will remain with me in my temptations"? And, following, "Just as my Father has prepared a kingdom for me, I will prepare for you a place at my table to eat and drink in my kingdom." And, elsewhere, "Blessed are those who suffer persecution for righteousness, for theirs is the kingdom of heaven. Blessed will you be when men speak evil of you and 
persecute you and lie and say all manner of evil against you. Rejoice and be exceeding glad, for great is your reward in heaven."

Therefore, let us follow Christ, the leader of his army of disciples, to the end. Let us attend to the teaching of the Master, who says, "He who wishes to come after me, let him deny himself," and so on. "He who loves his life shall lose it, and he who loses his life for me will find it in eternal life," dwelling with Christ, the King of Kings, throughout all ages, amen.

Greet for me Laudens and Grene, with his wife, and tell Grene to do nothing wrong, for there are two whom the Lord hates: the rich man who is a liar and the poor man who is proud, for he who shows pride shall not dwell in the house of the Lord.

And greet your mother for me, along with her daughter, your wife, with all the aforesaid greetings of eternal life and perpetual blessing. And greet for me, with the kiss of peace, all those beloved of God. Pray for me that God in his great mercy will direct my ways, so that I may persevere to the end, because he who perseveres all the way to the end shall be saved.

Also, I ask that you look in the small chest $\dagger \uparrow$. There you will find three books containing the four gospels all in one. In them is the text of Matthew, Mark, Luke, and John, written with red ink-and in the top margin is written "first part," "second part," "third part," and so on $\dagger \dagger$ in red ink. Likewise, I have two treatises there dealing with justice and law, containing about twelve, thirteen, or fourteen chapters. The first chapter starts on the third or fourth folio and deals with justice and law. On the first and second folios of the book is a summary of the chapters.

Get those five books for me, for the love of the living God. And if charity motivates you and you have a horse, you could carry those books to a priest living by the church of Saint Andrew, who, as I believe, is called Henry of
Topcliff, because he has a brother in Topcliff who is married to the sister of my lord William Corpp. That priest will see that I get them if he can, and also anything else you wish to send me. If you cannot come to him, send Grene's servant to go discreetly to that priest. If that priest sends you anything in return, he sends it on his initiative and not mine. So, likewise, send him whatever he wants; do not send it to me. Also, get me forty pence and get them back again from my brother.

If you cannot find those books, you will find in the other chest the five books of Moses or those of Solomon, written on paper by your own hand, I believe. Get them for me, in the name of charity.

I ask you to compose your reply and send it discreetly to the priest I mentioned above. I also ask that you keep this hidden. Using your judgment, do not reveal it to any but those who because of their love for me will keep their counsel. †Though my custodians are young, keep constant watch on what they do with me, because they are ignorant of these things. $\dagger$ Some say they will make it a solemn day.

Amen.

\section{TRANSLATOR'S NOTES}

1. Main canon law texts.

2. I.e., are the "accidents" (physical properties: taste, touch, appearance, smell) of bread severed from its material substance, which, the church teaches, no longer remains after consecration?

3. Wyche's syllogism:

Major premise: Anyone transgressing canon law is a heretic.

Minor premise: No heretic can consecrate the host.

Conclusion: Therefore, no one transgressing canon law can consecrate the host.

But if no one breaking man's (church or canon) law can consecrate, then a fortiori no one transgressing God's law can do so. Thus, a priest in a sinful state cannot consecrate-contrary to orthodox doctrine. 